\title{
Lipolysis and proteolysis profiles of fresh artisanal goat cheese made with raw milk with 3 different fat contents
}

\author{
D. Sánchez-Macías, A. Morales-delaNuez, I. Moreno-Indias, L. E. Hernández-Castellano, V. Mendoza-Grimón, \\ N. Castro, and A. Argüello ${ }^{1}$ \\ Department of Animal Science, Universidad de Las Palmas de Gran Canaria, Arucas 35413, Spain
}

\begin{abstract}
The objective of this study was to describe the proteolysis and lipolysis profiles in goat cheese made in the Canary Islands (Spain) using raw milk with 3 different fat contents $(0.5,1.5$, and 5\%) and ripened for 1, 7, 14, and $28 \mathrm{~d}$. $\beta$-Casein was the most abundant protein in all cheeses and at all ripening times. Quantitative analysis showed a general decrease in caseins as ripening progressed, and degradation rates were higher for $\alpha_{\mathrm{S}^{-}}$ casein than for $\beta$-casein and $\alpha_{S_{2}}$-casein. Furthermore, the degradation rate during the experimental time decreased with lower fat contents. The $\alpha_{S_{2} \text {-casein and }}$ $\alpha_{\mathrm{S}}$-casein levels that remained in full-fat and reducedfat cheeses were less than those in low-fat cheese. In contrast, $\beta$-casein also showed degradation along with ripening, but differences in degradation among the 3 cheese types were not significant at $28 \mathrm{~d}$. The degradation products increased with the ripening time in all cheeses, but they were higher in full-fat cheese than in reduced-fat and low-fat cheeses. The free fatty acid concentration per $100 \mathrm{~g}$ of cheese was higher in full-fat cheese than in reduced- and low-fat cheese; however, when the results were expressed as milligrams of free fatty acids per gram of fat in cheese, then lipolysis occurred more rapidly in low-fat cheese than in reducedand full-fat cheeses. These results may explain the atypical texture and off-flavors found in low-fat goat cheeses, likely the main causes of non-acceptance.
\end{abstract}

Key words: low-fat cheese, goat milk, proteolysis, lipolysis

\section{INTRODUCTION}

Goat milk production, and its transformation into value-added products such as cheese, has great importance because of the increasing demand for diverse and distinctive products and as an alternative for people who cannot tolerate cow milk (Tziboula-Clarke, 2003).

Received April 6, 2011.

Accepted September 5, 2011.

${ }^{1}$ Corresponding author: aarguello@dpat.ulpgc.es
Raw milk cheeses are an important part of the economy and traditions of the Canary Islands (Spain); about $17,000 \mathrm{t}$ of goat milk cheese are produced per year. Most of these products are made with raw milk using traditional methods and are mainly consumed following short ripening periods (about 7 d; Fresno et al., 2008). The Canary Islands are officially free of caprine and ovine brucellosis, and this exceptional sanitary situation has allowed about 500 artisan producers to obtain licenses to sell raw milk cheese within $60 \mathrm{~d}$ of ripening (Fresno and Álvarez, 2007). In contrast, new trends for healthier food choices and consumer interest for low-fat products have increased the attention for low-fat cheese (Johansen et al., 2011). Lipids are vital components of our diet; they are sources of energy and essential fatty acids. However, consumption of saturated fat is highly correlated with an increased risk of obesity, atherosclerosis, coronary artery disease, and elevated blood pressure (Watts et al., 1996; Van Horn and Ernest, 2001). Although this affirmation is nowadays in controversy (Astrup et al., 2011), the consumption of highly processed foods with refined starches, sugars, fats, and oils is increasing considerably and these foods often fail to contain the essential nutrients that are found in nutrient-dense foods (Kant, 2000). At the same time, labor-saving devices and advances in transportation have contributed to the highly sedentary lifestyle over the last 30 yr (Hill et al., 2003). Largely influenced by increase of consumer concerns, pressure has increased on the food industry to decrease the amount of fat, sugar, cholesterol, salt, and other components in the diet.

Three primary routes of biochemical activity exist in cheese during ripening: proteolysis; lipolysis; and the metabolism of lactate, citrate, and residual lactose (McSweeney, 2004a). Proteolysis is the most complex and, from the point of view of most investigators, the most important (McSweeney, 2004b). Proteolysis contributes to cheese ripening through a direct contribution to flavor via the formation of peptides and AA and by changing the texture of cheese from the breakdown of the protein network (Sousa et al., 2001). The technique of PAGE in the presence of SDS under reducing condi- 
tions (SDS-PAGE) is a fast, reproducible, and low-cost method that is widely used for quantifying, comparing, and characterizing proteins in goat cheese (Park, 2001).

Lipolysis in cheese is due to the presence of lipolytic enzymes that cleave the ester linkage between a fatty acid and the glycerol moiety of a triacylglycerol. It produces free fatty acids (FFA) with chain lengths $\geq \mathrm{C} 4$, glycerol, and mono- and diacylglycerols. Hexanoic, octanoic, and decanoic fatty acids have long been considered responsible for the characteristic aroma of goat (caprine) cheeses, giving rise to the terms caproic, caprylic, and capric acids. Additionally, certain branched-chain FFA contribute by themselves to the goaty flavor of cheese (Salles et al., 2002). Furthermore, the peculiarities of the goat milk lipolytic system (Chilliard, 1982) and the content of medium-chain fatty acids (Ha and Lindsay, 1993) could greatly change the FFA content, playing a major role in the distinctive flavor of goat milk (Chilliard et al., 2003).

Drake (2008) evaluated the consumer acceptance of low-fat cheeses, and identified various drawbacks to its use, including lack of flavor, rubbery texture, stickiness, low melt ability, and consumer perception as unnatural and unappealing compared with full-fat cheeses. Especially for some cheese varieties (e.g., hard Italian and blue-type cheeses), FFA are the major contributors to the development of their characteristic flavors (Fenelon and Guinee, 2000). Sensory profile and consumer preference tests have been made for the cheeses of the present study [D. Sánchez-Macías, I. Moreno-Indias, S. Álvarez (Canary Agronomic Science Institute, Tenerife, Spain), M. Clevelan (Dairy Products Technology Center, California Polytechnic State University, San Luis Obispo, CA), N. Castro, A. Argüello, and M. del Rosario Fresno (Canary Agronomic Science Institute); unpublished data], and both judges and consumers preferred the full-fat cheese (FFC) cheeses, mainly because of the higher intensity, and they rejected the counterpart low-fat cheeses due to the off-flavors and higher chewiness. It is not yet clear whether the lack of flavor in low-fat cheeses is due to the lack of flavor precursors derived from the fat, the lack of fat as a solvent for flavor compounds, or the different physical structures of reduced-fat cheese, which may decrease the rate of some enzymatic reactions that are essential to the formation of flavor compounds (Urbach, 1997).

The gross composition, texture profile, and color of artisanal raw goat cheeses from the Canary Islands that were produced with milk with different fat contents have been reported (Sánchez-Macías et al., 2010), but information about the protein profile and lipolysis level of these cheeses has not been determined. The aims of this study were to quantify and compare the protein profile using SDS-PAGE and the lipolysis level (as total FFA) of cheeses made from raw goat milk with 3 different fat contents and ripened for $28 \mathrm{~d}$ using an artisanal method.

\section{MATERIALS AND METHODS}

\section{Cheese Production}

Formulations. Raw goat milk cheeses were made according to traditional hand-made cheese practices common in the Canary Islands (Fresno and Álvarez, 2007) and were produced at the dairy farm of the Facultad de Veterinaria, Universidad de Las Palmas de Gran Canaria (Arucas, Spain). Raw goat milk was obtained from an experimental dairy goat herd (Majorera breed) from the Animal Science Unit of the Universidad de Las Palmas de Gran Canaria. Duplicate batches of experimental cheeses were produced and consisted of FFC, reduced-fat cheese (RFC), and low-fat cheese (LFC) ripened for $1,7,14$, or $28 \mathrm{~d}$ in triplicate, resulting in a total of 72 cheese products.

Processing. An Elecrem skimmer (Elecrem SA, Fresnes, France) was used to obtain cream (35\% fat content) and skim milk from $120 \mathrm{~L}$ of full-fat raw goat milk. Full-fat and skim milk were combined to obtain reduced-fat milk. The results were 3 different milk fat contents: full-fat milk ( $5 \%$ fat), reduced-fat milk (1.5\% fat), and low-fat milk ( $0.4 \%$ fat). The procedure to make each type of cheese with raw goat milk was exactly the same, using the method described by Sánchez-Macías et al. (2010), using animal rennet (Marshall rennet powder; Rhône-Poulenc Texel, Dangé-Saint-Romain, France) comprising $50 \%$ pepsin and $50 \%$ chymosin and no starter cultures were added. Curd was pressed in a cheese press (Arroyo Laboratories, Santander, Spain) at $2 \mathrm{kPa}$ of pressure for a 1-h period. After pressing, the cheeses were $10 \pm 0.1 \mathrm{~cm}$ in diameter and weighed 300 $\pm 15 \mathrm{~g}$. The cheeses for a given fat content were divided randomly into 4 groups of 6 cheeses and allowed to ripen for $1,7,14$, or $28 \mathrm{~d}$ at 10 to $12^{\circ} \mathrm{C}$ and 80 to $85 \%$ relative humidity.

\section{Chemical and $\mathrm{pH}$ Analyses}

At 1, 7, 14, and $28 \mathrm{~d}$ of ripening, representative samples from each cheese were homogenized and analyzed for proximal composition (fat, protein, moisture, and fat in DM) using an Instalab 600 NIR product analyzer (Dickey-John Inc., Minneapolis, MN), a reflection spectrophotometer that is based on near-infrared reflectance. The $\mathrm{pH}$ was measured at 3 internal and 3 external random locations for each cheese. 


\section{Extraction of Proteins and Electrophoretic Analysis}

All chemical reagents were of analytical grade from Panreac Química S.A.U. (Barcelona, Spain), Merck KGaA (Darmstadt, Germany), and Bio-Rad Laboratories Inc. (Hercules, CA). Water-soluble proteins were extracted from FFC, RFC, and LFC tested at 1, 7, 14 , and $28 \mathrm{~d}$ of ripening using the method described by Tunick et al. (1995) with modifications. Briefly, 5 $\mathrm{mL}$ of buffer (0.166 $M$ Tris, $0.001 M$ EDTA, pH 8.0) was added to $2 \mathrm{~g}$ of cheese and vortexed for $15 \mathrm{~min}$. To this mixture, $5 \mathrm{~mL}$ of $7 \%$ SDS was added, and the sample was vortexed again for $5 \mathrm{~min}$. Then $2 \mathrm{~mL}$ of 10 $\mathrm{m} M$ dithiothreitol buffer was added, and the mixture was vortexed and held in an ice bath for 20 to $30 \mathrm{~min}$. Samples were then centrifuged at 39,000 $\times g$ for $1 \mathrm{~h}$ at $4^{\circ} \mathrm{C}$ (Beckman J2-CI Centrifuge; Beckman Coulter Inc., Miami, FL). The supernatant was filtered, lyophilized, and stored at $-20^{\circ} \mathrm{C}$ until analysis.

Lyophilized samples were prepared for SDS-PAGE; a final concentration of $1 \mathrm{mg} / \mathrm{mL}$ of cheese protein was reached using sample buffer $(12.5 \%$ of $0.5 \mathrm{M}$ Tris- $\mathrm{HCl}$, pH $6.8 ; 25 \%$ glycerol; $2 \%$ SDS; and $0.4 \%$ of bromophenol blue). Each sample in buffer was boiled for 5 min at $100^{\circ} \mathrm{C}$ with $16 \mu \mathrm{L}$ of $\beta$-mercaptoethanol, and the proteins $(40 \mu \mathrm{g})$ were separated by SDS-PAGE (Laemmli, 1970) on a $12.5 \%$ gel. Gels were run at $100 \mathrm{~V}$ for $6 \mathrm{~h}$ and, after electrophoresis, gels were stained for $90 \mathrm{~min}$ using $10 \%$ acetic acid, $40 \%$ methanol, and $0.05 \%$ (wt/vol) Coomassie Blue R-250 solution, and then destained for $15 \mathrm{~h}$ using $10 \%$ acetic acid and $40 \%$ methanol solution. Images of stained gels were captured with a Bio-Rad imaging device (Gel Doc EQ; Bio-Rad Laboratories Inc.), and bands were quantified using Quantity One Quantitation Software (Bio-Rad Laboratories Inc.). Densitometry analysis of the gels was performed using lane-based background subtraction followed by measurement of the bands by the area under the intensity profile curve, and the values were then used for statistical analysis. Each sample was analyzed on duplicate gels. Individual protein species from the cheese samples were identified by comparing their relative mobilities with those of standard proteins (Bio-Rad Laboratories Inc.) from a previous SDS-polyacrylamide gel.

\section{Total FFA (Copper Soap Method)}

The total FFA content was determined using the copper soap method (Shipe et al., 1980; Ma et al., 2003; Melilli et al., 2004) as modified for cheese analysis. Ground cheese $(0.25 \mathrm{~g})$ at $4^{\circ} \mathrm{C}$ was placed in a centrifuge tube, $0.1 \mathrm{~mL}$ of $0.7 \mathrm{~N} \mathrm{HCl}$ was added, and the tube was vortexed to allow thorough mixing of the acid and cheese. Then, $0.1 \mathrm{~mL}$ of $1 \%$ (vol/vol) Triton X-100 solution was added, and the mixture was vortexed. The copper soap reagent $(2 \mathrm{~mL})$ was added, and the mixture was vortexed again. Chloroform/heptane/methanol $(49: 49: 2 \mathrm{vol} / \mathrm{vol} / \mathrm{vol})$ solvent $(6 \mathrm{~mL})$ was added to each tube without vortexing. The mixture had 2 distinct layers: the deep blue aqueous layer on the bottom and the colorless chloroform/heptane/methanol solvent layer on the top. The centrifuge tubes containing the reagents plus cheese samples were shaken for $60 \mathrm{~min}$ in a Heidolph Rotamax orbital platform shaker (Heidolph Instruments GmbH \& Co., Schwabach, Germany) at $300 \mathrm{rpm}$. During shaking, the deep blue aqueous copper soap layer broke into pea-sized beads that were in continuous contact with the colorless solvent. When shaking was stopped, 2 distinct layers quickly formed, and then the tubes were centrifuged (Hettich Zentrifugen $\mathrm{GmbH} \&$ Co. KG, Tuttlingen, Germany) at 3,500 $\times g$ for $10 \mathrm{~min}$. The top colorless solvent layer (3.5 $\mathrm{mL}$ ) was transferred from the centrifuge tubes into an acid-washed test tube containing $0.1 \mathrm{~mL}$ of the color reagent solution. After mixing, absorbance was measured immediately at $440 \mathrm{~nm}$ in a cuvette using a SmartSpec Plus spectrophotometer (Bio-Rad Laboratories Inc.). Two blanks $(0.5 \mathrm{~mL}$ of deionized water instead of 0.25 $\mathrm{g}$ of cheese) were also prepared and analyzed with the cheese samples.

A standard curve was constructed using palmitic acid crystal grade. Eleven concentrations of palmitic acid were prepared: $0,15,30,60,120,180,240,280$, 360,420 , and $600 \mu \mathrm{g}$ of palmitic acid/g of hexane. Each standard $(1 \mathrm{~mL})$ was added to a centrifuge tube. The hexane solvent was evaporated under the hood. After the solvent was completely removed, $1 \mathrm{~mL}$ of deionized water was added to the tube, and the set of standards was carried through the full analysis with the cheese samples and 2 blanks.

Absorbance readings of the standards were corrected by subtracting the average of the 2 blank readings, and a regression line was constructed that correlated the corrected absorbance with micrograms of palmitic acid. The level of FFA in the cheese samples was calculated from the standard curve. The final results were expressed as milligrams of FFA per $100 \mathrm{~g}$ of cheese and were also converted to milligrams of FFA per gram of fat in the cheese.

\section{Statistical Analysis}

Statistical analyses were performed using the SAS program package (Version 9.00; SAS Institute Inc., Cary, NC). A PROC MIXED procedure (ANOVA with repeated measures) was used to evaluate the effect of different fat contents and times of ripening and to evaluate proteolysis and lipolysis during the ripening 
process in all 3 types of cheeses. Significantly different means were identified using the Tukey test.

\section{RESULTS AND DISCUSSION}

\section{Physicochemical Cheese Analysis and pH Values}

The gross chemical composition and $\mathrm{pH}$ of cheeses throughout the 28 d of ripening (Sánchez-Macías et al., 2010) are shown in Table 1. As was expected, the percentage fat in $\mathrm{DM}$ was higher in FFC than in $\mathrm{RFC}$ or LFC at all days tested during ripening. On $\mathrm{d} 1$ of ripening, the protein and moisture content was higher in LFC than in RFC and FFC. The moisture decreased in all 3 cheese types throughout the study because of surface water evaporation.

The external and internal $\mathrm{pH}$ was approximately 6.6 in FFC, RFC, and LFC at $1 \mathrm{~d}$ of ripening. During the first and second weeks of ripening, external and internal $\mathrm{pH}$ values decreased in all cheese groups. At 28 $\mathrm{d}$ of ripening, the $\mathrm{pH}$ increased in RFC and LFC, likely due to the release of basic AA and the decomposition of $\mathrm{NH}_{3}$ and lactate (Alais, 1985). In FFC at $28 \mathrm{~d}$ of ripening, the $\mathrm{pH}$ value was similar to that observed at $14 \mathrm{~d}$ of ripening. The $\mathrm{pH}$ increase observed at $\mathrm{d} 28$ in $\mathrm{RFC}$ and LFC may be attributed to a concomitant decrease in the level of moisture in non-fat solids and, hence, in the lactate-to-protein ratio (Fenelon and Guinee, 2000). Taken together, these data indicate that as the fat was reduced, the external and internal $\mathrm{pH}$ increased. Small increases in moisture in nonfat solids led to relatively large increases in available water, which in turn resulted in increases in the activity of microorganisms and enzyme and the degree of proteolysis in cheese (Ruegg and Blanc, 1981).

\section{Proteolysis Analysis with SDS-PAGE}

The SDS-PAGE patterns of proteins extracted from cheese with different fat contents and ripened for 1,7 , 14 , and $28 \mathrm{~d}$ showed clear bands for caseins $\alpha_{\mathrm{S1}}-\mathrm{CN}$, $\alpha_{\mathrm{S} 2}-\mathrm{CN}, \beta-\mathrm{CN}$, para- $\kappa-\mathrm{CN}$, and fragments of protein degradation (Figure 1). A densitometer protein-peptide distribution analysis is summarized in Table 2 . In all cheese types and at all ripening times, the $\beta-\mathrm{CN}$ bands showed the highest intensities, followed by $\alpha_{\mathrm{S}_{2}} \mathrm{CN}$ and then $\alpha_{\mathrm{S} 1}-\mathrm{CN}$. The presence of para- $\kappa-\mathrm{CN}$, which corresponds to the $\kappa-\mathrm{CN}$ (f1-105) fragment, was stable throughout the $28 \mathrm{~d}$ of ripening, with slight degradation apparent at the end of the experimental period.

In general, caprine milk contains no or relatively little $\alpha_{\mathrm{S} 1}-\mathrm{CN}$, whereas $\beta-\mathrm{CN}$ is the major protein (TziboulaClarke, 2003). The Canarian dairy breeds (Majorera, Tinerfeña, and especially Palmera) represent a particular case where $60 \%$ of the alleles for the caprine $\alpha_{\mathrm{S} 1}-\mathrm{CN}$ locus are of the high type (A and $\mathrm{B}$; Jordana et al., 1996); therefore, $\alpha_{\mathrm{S} 1}-\mathrm{CN}$ is relatively abundant in milk and cheeses made from these breeds. On average, $\alpha_{S_{1}-} \mathrm{CN}$ in caprine milk represents $10 \%$ of total caseins, varying from 0 to $25 \%$ (Boulanger et al., 1984; Ciafarone and Addeo, 1984), depending on the animal

Table 1. Chemical composition, external and internal $\mathrm{pH}$ values (means and SEM) of full-fat cheese (FFC), reduced-fat cheese (RFC), and low-fat cheese (LFC) at 1, 7, 14, and 28 d of ripening (Sánchez-Macías et al., 2010)

\begin{tabular}{|c|c|c|c|c|c|c|}
\hline \multirow[b]{2}{*}{ Item } & \multirow{2}{*}{$\begin{array}{l}\text { Cheese } \\
\text { type }\end{array}$} & \multicolumn{4}{|c|}{ Ripening duration } & \multirow[b]{2}{*}{ SEM } \\
\hline & & $1 \mathrm{~d}$ & $7 \mathrm{~d}$ & $14 \mathrm{~d}$ & $28 \mathrm{~d}$ & \\
\hline \multirow[t]{3}{*}{ Moisture, \% } & FFC & $46.95^{\mathrm{a}, \mathrm{x}}$ & $45.92^{\mathrm{a}, \mathrm{x}}$ & $44.12^{\mathrm{b}, \mathrm{x}}$ & $40.32^{\mathrm{c}, \mathrm{x}}$ & 0.57 \\
\hline & $\mathrm{RFC}$ & $52.00^{\mathrm{a}, \mathrm{y}}$ & $51.61^{\mathrm{a}, \mathrm{y}}$ & $50.98^{\mathrm{a}, \mathrm{y}}$ & $49.20^{\mathrm{b}, \mathrm{y}}$ & 0.29 \\
\hline & LFC & $55.69^{\mathrm{a}, \mathrm{z}}$ & $55.28^{\mathrm{a}, \mathrm{z}}$ & $55.15^{\mathrm{a}, \mathrm{z}}$ & $51.18^{\mathrm{b}, \mathrm{z}}$ & 0.41 \\
\hline \multirow[t]{3}{*}{ Fat, $\%$} & FFC & $18.48^{\mathrm{d}, \mathrm{z}}$ & $22.19^{\mathrm{c}, \mathrm{z}}$ & $25.01^{\mathrm{b}, \mathrm{z}}$ & $28.61^{\mathrm{a}, \mathrm{z}}$ & 0.89 \\
\hline & RFC & $9.38^{\mathrm{b}, \mathrm{y}}$ & $10.69^{\mathrm{b}, \mathrm{y}}$ & $12.17^{\mathrm{ab}, \mathrm{y}}$ & $13.61^{\mathrm{a}, \mathrm{y}}$ & 0.39 \\
\hline & LFC & $1.12^{\mathrm{c}, \mathrm{x}}$ & $2.60^{\mathrm{bc}, \mathrm{x}}$ & $4.43^{\mathrm{b}, \mathrm{x}}$ & $8.81^{\mathrm{a}, \mathrm{x}}$ & 0.64 \\
\hline \multirow[t]{3}{*}{ Protein, \% } & FFC & $18.94^{\mathrm{b}, \mathrm{x}}$ & $20.51^{\mathrm{a}, \mathrm{x}}$ & $20.47^{\mathrm{a}, \mathrm{x}}$ & $19.96^{\mathrm{a}, \mathrm{x}}$ & 0.18 \\
\hline & $\mathrm{RFC}$ & $20.97^{\mathrm{c}, \mathrm{y}}$ & $23.01^{\mathrm{b}, \mathrm{y}}$ & $24.38^{\mathrm{a}, \mathrm{y}}$ & $24.65^{\mathrm{a}, \mathrm{y}}$ & 0.35 \\
\hline & LFC & $22.84^{\mathrm{d}, \mathrm{z}}$ & $25.90^{c, z}$ & $29.37^{\mathrm{b}, \mathrm{z}}$ & $32.66^{\mathrm{a}, \mathrm{z}}$ & 0.80 \\
\hline \multirow[t]{3}{*}{ Fat in DM, \% } & FFC & $37.88^{\mathrm{d}, \mathrm{z}}$ & $41.03^{\mathrm{c}, \mathrm{z}}$ & $44.75^{\mathrm{b}, \mathrm{z}}$ & $47.93^{\mathrm{a}, \mathrm{z}}$ & 0.87 \\
\hline & $\mathrm{RFC}$ & $19.54^{\mathrm{c}, \mathrm{y}}$ & $21.93^{\mathrm{b}, \mathrm{y}}$ & $24.85^{\mathrm{a}, \mathrm{y}}$ & $26.78^{\mathrm{a}, \mathrm{y}}$ & 0.68 \\
\hline & LFC & $2.48^{\mathrm{d}, \mathrm{x}}$ & $5.79^{\mathrm{c}, \mathrm{x}}$ & $9.88^{\mathrm{b}, \mathrm{x}}$ & $18.08^{\mathrm{a}, \mathrm{x}}$ & 1.28 \\
\hline \multirow[t]{3}{*}{ External pH } & FFC & $6.58^{\mathrm{a}, \mathrm{z}}$ & $5.03^{\mathrm{b}, \mathrm{z}}$ & $4.92^{\mathrm{c}, \mathrm{z}}$ & $4.90^{\mathrm{c}, \mathrm{x}}$ & 0.15 \\
\hline & RFC & $6.57^{\mathrm{a}, \mathrm{z}}$ & $5.10^{\mathrm{b}, \mathrm{z}}$ & $4.89^{\mathrm{c}, \mathrm{z}}$ & $5.01^{\text {b,y }}$ & 0.14 \\
\hline & LFC & $6.59^{\mathrm{a}, \mathrm{z}}$ & $5.10^{\mathrm{c}, \mathrm{z}}$ & $4.99^{\mathrm{d}, \mathrm{z}}$ & $5.38^{\mathrm{b}, \mathrm{z}}$ & 0.13 \\
\hline \multirow[t]{3}{*}{ Internal $\mathrm{pH}$} & FFC & $6.58^{\mathrm{a}, \mathrm{z}}$ & $4.99^{\mathrm{b}, \mathrm{z}}$ & $4.74^{\mathrm{c}, y}$ & $4.81^{\mathrm{c}, \mathrm{x}}$ & 0.16 \\
\hline & RFC & $6.56^{\mathrm{a}, \mathrm{z}}$ & $5.06^{\mathrm{b}, \mathrm{z}}$ & $4.82^{\mathrm{d}, \mathrm{y}}$ & $4.94^{\mathrm{c}, \mathrm{y}}$ & 0.15 \\
\hline & LFC & $6.58^{\mathrm{a}, \mathrm{z}}$ & $5.08^{\mathrm{c}, \mathrm{z}}$ & $4.91^{\mathrm{d}, \mathrm{z}}$ & $5.32^{\mathrm{b}, \mathrm{z}}$ & 0.14 \\
\hline
\end{tabular}

$\overline{\mathrm{a}-\mathrm{d}}$ Means within a row with different superscript letters differ significantly $(P<0.05)$.

${ }^{\mathrm{x}-\mathrm{z}}$ Means within a column for a specific item with different superscript letters differ significantly $(P<0.05)$. 


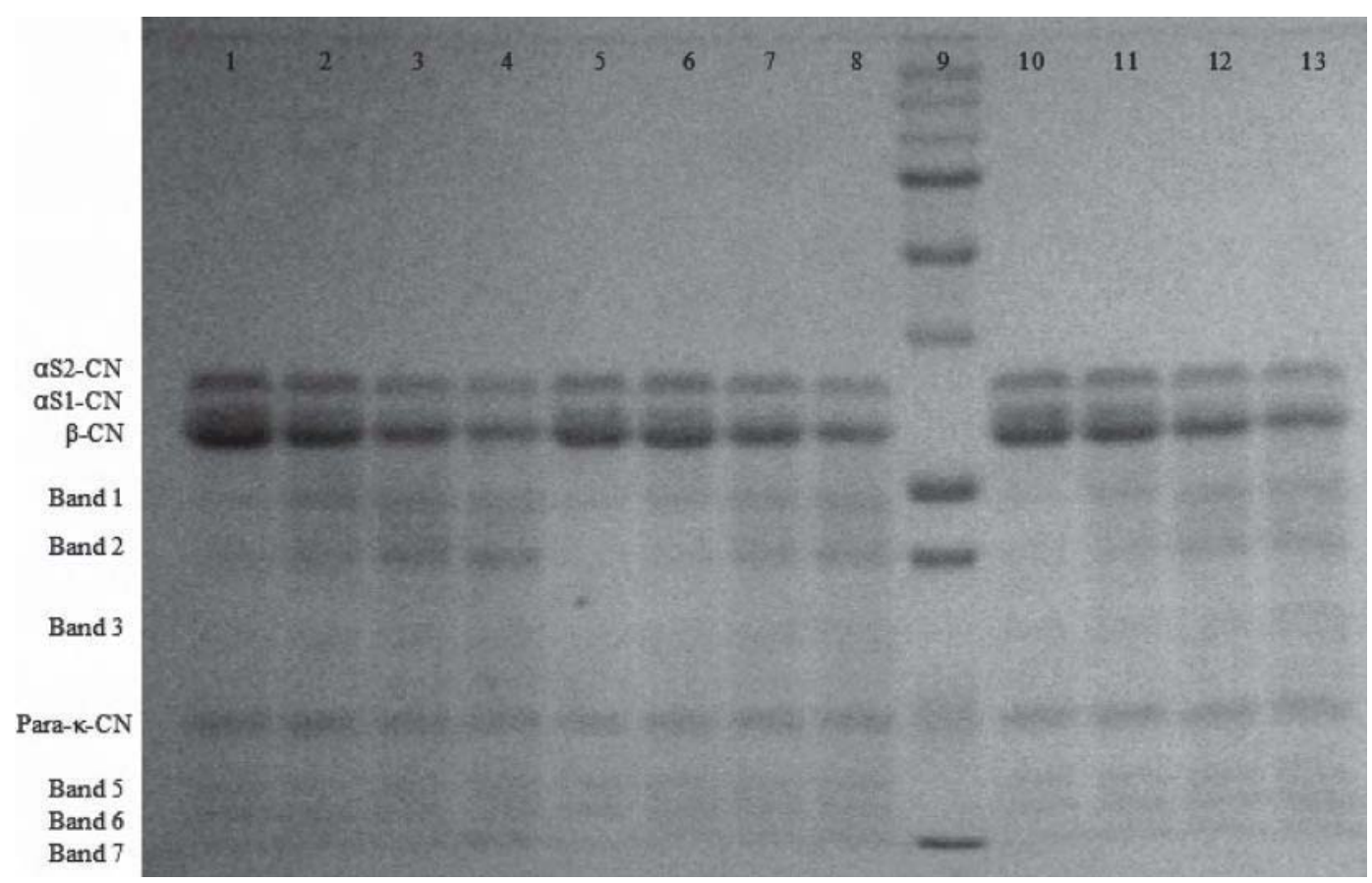

Figure 1. Sodium dodecyl sulfate PAGE pattern of caseins and other proteins (bands 1-3 and 5-7 are fragments of protein degradation) in goat milk cheese. Proteins were extracted from full-fat cheese (FFC), reduced-fat cheese (RFC), and low-fat cheese (LFC) and separated on a denaturing $12.5 \%$ polyacrylamide gel. Lanes 1 to 4 = degradation pattern of proteins from FFC aged for 1, 7, 14, and 28 d; lanes 5 to 8 , degradation pattern of proteins from RFC aged for 1, 7, 14, and 28 d; lanes 10 to 13 = degradation pattern of proteins from LFC aged for 1, 7, 14, and 28 d; lane $9=$ molecular weight protein standard (Precision Plus Protein Standards; Bio-Rad Laboratories Inc., Hercules, CA).

genotype. In the present study, $\alpha_{\mathrm{S} 1^{-}} \mathrm{CN}$ was about 20 to $22 \%$ of the total intact caseins in all cheese types at 1 $\mathrm{d}$ of ripening.

Quantitative analysis showed a general decrease in casein fractions as ripening progressed for all 3 cheese types, and the degradation of intact caseins were higher for $\alpha_{\mathrm{S}^{-}} \mathrm{CN}(60-70 \%)$ than for $\beta-\mathrm{CN}(38-45 \%)$ and $\alpha_{\mathrm{S}^{-}}$ CN (25-40\%) over the $28 \mathrm{~d}$ of maturation. Trujillo et al. (1997b) found exactly the same order of susceptibility of the different casein components to rennet activity. Furthermore, the casein degradation rate was lower in cheeses with reduced fat contents. At $28 \mathrm{~d}$, the percentage of total caseins remaining was $62,66.5$, and $70 \%$ in FFC, RFC, and LFC, respectively, as compared with the amount at $1 \mathrm{~d}$ of ripening. The remaining $\alpha_{\mathrm{S}_{2}} \mathrm{CN}$ and $\alpha_{\mathrm{S}_{1}} \mathrm{CN}$ levels in FFC and RFC were lower than in LFC. $\alpha_{\mathrm{S} 1}$-Casein degraded faster; the cheeses contained 28 to $40 \% \alpha_{S_{1}-}$ CN at $28 \mathrm{~d}$ of ripening. $\alpha_{\mathrm{S}_{2}}$ Casein degraded more slowly in LFC than in FFC and RFC. Other authors have also found that decreasing the fat content results in higher levels of intact $\alpha_{\mathrm{S}_{1}} \mathrm{CN}$ and $\beta-\mathrm{CN}$ in cheddar (Fenelon and Guinee, 2000) and mozzarella (Tunick et al., 1993, 1995) cheeses made with cow milk. Fenelon and Guinee (2000) showed that fat in the range of 6 to $33 \%$ had a marked influence on the level of proteolysis in cheddar cheese manufactured using identical conditions but with a different level of moisture in nonfat solids. With a fixed concentration of casein, $\alpha_{\mathrm{S}^{-}} \mathrm{CN}$ degraded more slowly and $\beta$-CN degraded more rapidly as the fat content was decreased. In this study, the degradation slowed down only for $\alpha_{\mathrm{S}^{-}} \mathrm{CN}$ and $\alpha_{\mathrm{S}^{2}} \mathrm{CN}$ in LFC. This effect may be due to several associated factors: the decrease in the ratio of the residual rennet activity to the protein level (Fenelon and Guinee, 2000) and the high $\mathrm{pH}$ of low-fat cheeses, which is less favorable to the proteolytic activity of residual rennet (Tam and Whitaker, 1972; O'Keeffe et al., 1976). In low-fat cheeses, proteolysis of casein is inadequate, resulting in a relatively firm texture (Mistry et al., 1996; Mistry, 2001), and the results reported in the current paper are supported with those for higher instrumental hardness and masticability found by Sánchez-Macías et al. (2010) in the same cheeses. These authors found that fracturability, hardness, and cohesiveness were higher in low-fat cheese than full-fat cheese during $28 \mathrm{~d}$ of ripening. In the first $14 \mathrm{~d}$ of ripening, rubbery young cheese curd is rapidly changed to a smoother, more homogeneous texture, due to the fact that the casein network is considerably weakened through proteolysis (Creamer and Richardson, 1974; Lawrence et al., 1987).

Trujillo et al. (1995, 1997a,b) showed that the hydrolysis of goat casein by rennet and pepsin results in 
certain-sized peptides that can be identified by their migration rates in SDS-polyacrylamide gels. In this study, the breakdown products of casein in the experimental cheeses were quantitatively analyzed and generally increased over the ripening time for all cheeses. We have focused on the major peptides that appear, although other casein fragments may also have been present. The amount of these fragments was higher in FFC than in RFC and LFC. Thus, the degradation rate of caseins increased as the fat content in cheese increased, resulting in the appearance of more low-molecular weight bands in FFC. These low-molecular weight species are labeled bands 1 to 3 , para- $\kappa-\mathrm{CN}$, and bands 5 to 7 in Figure 1.

Band 1, just below $\beta$-CN, is related to $\gamma$-CN (Park, $2001)$ and did not vary significantly in cheese with different fat contents during $28 \mathrm{~d}$ of ripening. An increase in this fragment was observed in all cheese types at $7 \mathrm{~d}$, but the level was stable between 7 and $28 \mathrm{~d}$. A concomitant decrease in $\beta$-CN was observed with the increase in the band- 1 protein, a finding that was also observed previously (Park, 2001). According to Trujillo et al. $(1995,1997 \mathrm{a}, \mathrm{b})$, the region where bands 2 and 3 appeared (with a molecular weight between those of $\beta-\mathrm{CN}$ and $\beta-\mathrm{LG}$ ) is where the larger peptides from $\beta$-CN hydrolysis are expected to migrate, including the chymosin-generated series of $\beta-\mathrm{CN}$ (1-192, 1-163, and $1-139$ fragments) and plasmin-generated $\beta-\mathrm{CN}$ (f29207). For both bands 2 and 3, differences were found in the rate of appearance among cheese types; the bands emerged earlier in FFC than in RFC and LFC. Band 2 was more prevalent than band 3. Trujillo et al. (1997b) reported that the hydrolysis of $\alpha_{\mathrm{S2}^{2}} \mathrm{CN}$ by rennet resulted in the appearance of low-molecular weight bands in the region between 10 and $14 \mathrm{kDa}$, where bands 5 , 6 , and 7 are presented on the gel. Bands 5 and 6 were present at a low level over time in the 3 types of cheese, except that band 5 and band 6 increased at $28 \mathrm{~d}$ in FFC and LFC, respectively. Band 7 clearly increased over the $28 \mathrm{~d}$ of maturation in all 3 cheese types to a similar extent.

\section{Lipolysis Analysis by Total FFA Determination}

Means of total FFA per $100 \mathrm{~g}$ of cheese and per gram of fat of cheeses throughout the $28 \mathrm{~d}$ of ripening are shown in Table 3. At all ripening times, FFC had the highest value of total FFA/100 g of cheese (Table 3a). Full-fat cheese exhibited a high increase in total FFA during the ripening time until $14 \mathrm{~d}$; the value remained unchanged at $28 \mathrm{~d}$ of ripening. For RFC and LFC, the total values of $\mathrm{FFA} / 100 \mathrm{~g}$ of cheese remained similar without significant differences, except for a significant increase in RFC on d 28 as compared with the first 
Table 3. Total free fatty acids (FFA) in full-fat cheese (FFC), reduced-fat cheese (RFC), and low-fat cheese (LFC) at $1,7,14$, and 28 d of ripening

\begin{tabular}{|c|c|c|c|c|c|}
\hline \multirow[b]{2}{*}{ Item } & \multicolumn{4}{|c|}{ Ripening duration } & \multirow[b]{2}{*}{ SEM } \\
\hline & $1 \mathrm{~d}$ & $7 \mathrm{~d}$ & $14 \mathrm{~d}$ & $28 \mathrm{~d}$ & \\
\hline \multicolumn{6}{|c|}{ Total FFA, mg/100 g of cheese } \\
\hline $\mathrm{RFC}$ & $47.61^{\mathrm{ab}, \mathrm{y}}$ & $32.68^{\mathrm{b}, \mathrm{y}}$ & $57.41^{\mathrm{ab}, \mathrm{y}}$ & $87.27^{\mathrm{a}, \mathrm{y}}$ & 6.94 \\
\hline LFC & $36.83^{\mathrm{a}, \mathrm{y}}$ & $40.65^{\mathrm{a}, \mathrm{y}}$ & $31.02^{\mathrm{a}, \mathrm{y}}$ & $28.10^{\mathrm{a}, \mathrm{x}}$ & 2.66 \\
\hline \multicolumn{6}{|c|}{ Total FFA, mg/g of fat in cheese } \\
\hline LFC & $34.73^{\mathrm{a}, \mathrm{z}}$ & $17.46^{\mathrm{b}, \mathrm{z}}$ & $6.91^{\mathrm{c}, \mathrm{y}}$ & $3.15^{\mathrm{c}, \mathrm{y}}$ & 3.09 \\
\hline
\end{tabular}

\footnotetext{
${ }^{a-c}$ Means within a row with different superscript letters differ significantly $(P<0.05)$.

${ }^{\mathrm{x}-\mathrm{z}}$ Means within a column with different superscript letters differ significantly $(P<0.05)$.
}

week of ripening. A decrease in the total FFA level occurs in other cheese varieties as the fat content is decreased (Banks et al., 1989; Aly, 1994; Kondyli et al., 2002).

The levels of total FFA per $100 \mathrm{~g}$ of cheese suggest that the lipolysis rate increases as fat content in cheese increases, but if the total FFA value is expressed per gram of fat in cheese (Table 3b), it is apparent that the fat was hydrolyzed faster in LFC than in FFC. After $1 \mathrm{~d}$ of ripening, total FFA in LFC per gram of fat was much higher than that in FFC and RFC. Thus, other parameters in the cheese appear to have an influence on lipolysis. Gunasekaran and Ding (1999) examined the 3-dimensional characteristics of fat globules in Cheddar cheese of varying fat content (4-34\%) and found that at the lowest fat content, globule size was smallest but more globules were noted. Guinee et al. (2000) observed that, in Cheddar cheese (7-30\% fat content), a decrease in the fat content resulted in progressive clumping and coalescence of the globules. Microstructural and physicochemical dynamics of fat globules also appear to influence the localization and retention of starter lactococci in cheese: compared with Cheddar with a $50 \%$ fat reduction, full-fat Cheddar cheese retains a higher bacterial population in the curds, and these bacteria are located on the periphery of the fat globules (Laloy et al., 1996). Thus, the smaller size (and consequent higher total fat globule surface area and interface for lipase activity) and localization of lactic acid bacteria could explain the higher rate of lipolysis in LFC than in FFC.

Over the course of the 28-d ripening period, the total FFA per gram of fat in LFC decreased, possibly as a result of the catabolism of FFA. In RFC, the total FFA per gram of fat did not change over the ripening time, which may be due to equilibrium between FFA liberation and FFA degradation. The FFA per gram of fat in FFC increased during the first $14 \mathrm{~d}$ but decreased by $\mathrm{d} 28$. The lack of fat and the faster FFA liberation in LFC and RFC may promote early FFA metabolism and, thus, modify the flavor that is characteristic of FFC.

\section{CONCLUSIONS}

Fat reduction in traditional hand-made cheese resulted in higher protein and moisture content and $\mathrm{pH}$ values. The degradation rate of caseins decreased with the lower fat content, resulting in fewer low-molecular weight bands in RFC and LFC. The FFA concentration per $100 \mathrm{~g}$ of cheese was always higher in FFC than in RFC and LFC, but lipolysis expressed as total FFA per gram of fat in cheese increased as the fat content decreased.

\section{REFERENCES}

Alais, C. H. 1985. Ciencia de la Leche. Principios de la Técnica Lechera. 2nd ed. Reverté, Barcelona, Spain.

Aly, M. E. 1994. Flavour-enhancement of low-fat Kashkaval cheese using heat- or freeze-shocked Lactobacillus delbrueckii var. helveticus cultures. Nahrung 38:504-510.

Astrup, A., J. Dyerberg, P. Elwood, K. Hermansen, F. B. Hu, M. U. Jakobsen, F. J. Kok, R. M. Krauss, J. M. Lecerf, P. LeGrand, P. Nestel, U. Risérus, T. Sanders, A. Sinclair, S. Stender, T. Tholstrup, and W. C. Willett. 2011. The role of reducing intakes of saturated fat in the prevention of cardiovascular disease: Where does the evidence stand in 2010? Am. J. Clin. Nutr. 93:684-688.

Banks, J. M., E. Y. Brechany, and W. W. Christie. 1989. The production of low-fat Cheddar-type cheese. Int. J. Dairy Technol. $42: 6-9$

Boulanger, A., F. Grosclaude, and M.-F. Mahé. 1984. Polymorphisme des caséines $\alpha_{\mathrm{s} 1}$ et $\alpha_{\mathrm{s} 2}$ de la chèvre (Capra hircus). Genet. Sel. Evol. 16:157-176.

Chilliard, T. 1982. Variations physiologiques des activités lipasiques et de la liopolyse spontanée s les laits de vache, de chèvre et de femme: Revue bibliographique. Lait 62:1-31, 126-154.

Chilliard, Y., A. Ferlay, J. Rouel, and G. Lamberet. 2003. A review of nutritional and physiological factors affecting goat milk lipid synthesis and lipolysis. J. Dairy Sci. 86:1751-1770.

Ciafarone, N., and F. Addeo. 1984. Composizione della caseina e propieta del latte di capra. Il Vergaro 11:17-24.

Creamer, L. K., and B. C. Richardson. 1974. Identification of the primary degradation product of $\alpha_{S_{1}}$-casein in Cheddar cheese. N.Z. J. Dairy Sci. Tech. 9:9-13. 
Drake, M. A. 2008. The impact of fat content on flavor of Cheddar cheese. J. Dairy Sci. 91(E-Suppl. 1):152.

Fenelon, M. A., and T. P. Guinee. 2000. Primary proteolysis and textural changes during ripening in Cheddar cheese manufactured to different fat contents. Int. Dairy J. 10:151-158.

Fresno, M., and S. Álvarez. 2007. Análisis sensorial de los quesos de cabra de pasta prensada. Manual de cata para el queso Majorero DOP y Palmero DOP. M. del Rosario Fresno and S. Álvarez, ed. Instituto Canario de Investigaciones Agrarias, La Laguna, España. ISBN: 978-84-690-9887-5.

Fresno, M., A. Rodríguez, A. Escudero, R. González, P. Calero, S. Menéndez, and S. Álvarez. 2008. ¿Es posible elaborar quesos de leche cruda sin riesgos sanitarios? Ejemplo de los quesos Majoreros y Palmeros. Memorias IX Simposio Iberoamericano sobre la conservación y utilización de recursos zoogenéticos. R. D. Martínez, ed. ISBN 978-978-9455-72-2, 393-395, Mar de Plata, Argentina.

Guinee, T. P., M. A. E. Auty, and M. A. Fenelon. 2000. The effect of fat content on the rheology, microstructure and heat-induced functional characteristics of Cheddar cheese. Int. Dairy J. 10:277-288.

Gunasekaran, S., and K. Ding. 1999. Three dimensional characteristics of fat globules in Cheddar cheese. J. Dairy Sci. 82:1890-1896.

Ha, J. K., and R. C. Lindsay. 1993. Release of volatile branched-chain and other fatty acids from ruminal milk fats by various lipases. J. Dairy Sci. 76:677-690.

Hill, J. O., H. R. Wyatt, G. W. Reed, and J. C. Peters. 2003. Obesity and the environment: Where do we go from here? Science 299:853-855

Johansen, S. B., T. Næs, and M. Hersleth. 2011. Motivation for choice and healthiness perception of calorie-reduced dairy products. A cross-cultural study. Appetite 56:15-24.

Jordana, J., M. Amills, E. Diaz, C. Angulo, J. M. Serradilla, and A Sanchez. 1996. Gene frequencies of caprine $\alpha_{S_{1}}$-casein polymorphism in Spanish goat breeds. Small Rumin. Res. 20:215-221.

Kant, A. K. 2000. Consumption of energy-dense, nutrient-poor foods by adult Americans: Nutritional and health implications. The third National Health and Nutrition Examination Survey, 19881994. Am. J. Clin. Nutr. 72:929-936.

Kondyli, E., M. C. Katsiari, T. Masouras, and L. P. Voutsinas. 2002. Free fatty acids and volatile compounds of low-fat Feta-type cheese made with a commercial adjunct culture. Food Chem. 79:199 205.

Laemmli, U. K. 1970. Cleavage of structural proteins during the assembly of the head of bacteriophage T4. Nature 227:680-685.

Laloy, E., J. C. Vuillemard, M. El Soda, and R. E. Simard. 1996. Influence of the fat content Cheddar cheese on the retention and localization of starters. Int. Dairy J. 6:729-740.

Lawrence, R. C., L. K. Creamer, and J. Gilles. 1987. Texture development during cheese ripening. J. Dairy Sci. 70:1748-1760.

Ma, Y., D. M. Barbano, and M. Santos. 2003. Effect of $\mathrm{CO}_{2}$ addition to raw milk on proteolysis and lipolysis at $4^{\circ} \mathrm{C}$. J. Dairy Sci. 86:1616-1631.

McSweeney, P. L. H. 2004a. Biochemistry of cheese ripening. Int. J. Dairy Technol. 57:127-144.

McSweeney, P. L. H. 2004b. Biochemistry of cheese ripening: Introduction and overview. Pages 347-360 in Cheese: Chemistry, Physics and Microbiology. General Aspects. Vol. 1. 3rd ed. P. F. Fox, P. L. H. McSweeney, T. M. Cogan, and T. P. Guinee, ed. Academic Press, London, UK.

Melilli, C., D. M. Barbano, M. Manenti, J. M. Lynch, S. Carpino, and G. Licitra. 2004. Lipolysis and proteolysis in Ragusano cheese dur- ing brine salting at different temperatures. J. Dairy Sci. 87:23592374.

Mistry, V. V. 2001. Low-fat cheese technology. Int. Dairy J. 11:413422.

Mistry, V. V., L. E. Metzger, and J. L. Maubois. 1996. Use of ultrafiltered sweet buttermilk in the manufacture of reduced-fat Cheddar cheese. J. Dairy Sci. 79:1137-1145.

O'Keeffe, R. B., P. F. Fox, and C. Daly. 1976. Contribution of rennet and starter proteases to proteolysis in Cheddar cheese. J. Dairy Res. 43:97-107.

Park, Y. W. 2001. Proteolysis and lipolysis of goat milk cheese. J. Dairy Sci. 84(E. Suppl.):E84-E92.

Ruegg, M., and B. Blanc. 1981. Influence of water activity on the manufacture and ageing of cheese. Pages 791-811 in Water Activity: Influences on Food Quality. L. B. Rockland and G. F. Stewart, ed. Academic Press, New York, NY.

Salles, C., N. Sommerer, C. Septier, S. Issanchou, C. Chabanet, A. Garem, and J.-L. Le Quéré. 2002. Goat cheese flavor: Sensory evaluation of branched-chain fatty acids and small peptides. J. Food Sci. 67:835-841.

Sánchez-Macías, D., M. Fresno, I. Moreno-Indias, N. Castro, A. Morales-delaNuez, S. Álvarez, and A. Argüello. 2010. Physicochemical analysis of full-fat, reduced-fat, and low-fat artisan-style goat cheese. J. Dairy Sci. 93:3950-3956.

Shipe, W. F., G. F. Senyk, and K. B. Fountain. 1980. Modified copper soap solvent extraction method for measuring free fatty acids in milk. J. Dairy Sci. 63:193-198.

Sousa, M. J., Y. Ardö, and P. L. H. McSweeney. 2001. Advances in the study of proteolysis during cheese ripening. Int. Dairy J. $11: 327-345$.

Tam, J. J., and J. R. Whitaker. 1972. Rates and contents of hydrolysis of several caseins by pepsin, rennin, Endothia parasitica protease and Mucor pusillus protease. J. Dairy Sci. 55:1523-1531.

Trujillo, A.-J., B. Guamis, and C. Carretero. 1995. Proteolysis of goat $\beta$-casein by calf rennet under various factors affecting the cheese ripening process. J. Agric. Food Chem. 43:1472-1478.

Trujillo, A. J., B. Guamis, and C. Carretero. 1997a. Hydrolysis of caprine $\beta$-casein by plasmin. J. Dairy Sci. 80:2258-2263.

Trujillo, A. J., B. Guamis, and C. Carretero. 1997b. Proteolysis of goat casein by calf rennet. Int. Dairy J. 7:579-588.

Tunick, M. H., K. L. Mackey, J. J. Shieh, P. W. Smith, P. Cooke, and E. L. Malin. 1993. Rheology and microstructure of low-fat Mozzarella cheese. Int. Dairy J. 3:649-662.

Tunick, M. H., E. L. Malin, P. W. Smith, and V. H. Holsinger. 1995. Effects of skim milk homogenization on proteolysis and rheology of Mozzarella cheese. Int. Dairy J. 5:483-491.

Tziboula-Clarke, A. 2003. Goat milk. Pages 1270-1279 in Encyclopedia of Dairy Sciences. H. Roginski, J. W. Fuquay, and P. F. Fox, ed. Academic Press, Cornwall, UK.

Urbach, G. 1997. The flavour of milk and dairy products. II. Cheese: Contribution of volatile compounds. Int. J. Dairy Technol. 50:7989.

Van Horn, L., and N. Ernest. 2001. Summary of the science supporting the new National Cholesterol Education Program dietary recommendations: What dietitians should know. J. Am. Diet. Assoc. 101:1148-1154.

Watts, G. F., P. Jackson, V. Burke, and B. Lewis. 1996. Dietary fatty acids and progression of coronary artery disease in men. Am. J. Clin. Nutr. 64:202-209. 